\title{
TEACHER ACT IN CLASSROOM INTERACTION BASED ON SINCLAIR AND COULTHARD MODEL
}

\author{
*IntanPermataBunda \\ ** SitiAisahGinting \\ ** IsliIrianiIndiah Pane
}

\begin{abstract}
This study focused on teacher act in classroom interaction based on Sinclair and Coulthard Model. The aims of this study are (a) to find out the types of act in classroom interaction that the teacher used based on Sinclair and Coulthard Model, (b) to describe how the types of acts are realized in classroom interaction that the teacher used based on Sinclair and Coulthard Model. This research used qualitative research. To answer the problems of the study, the data were collected in two ways by observing, and recording. The data were analyzed based on Sinclair and Coulthard model. The results of this research were the following: (a) there were 16 types of acts in teacher utterances, namely: Marker, Starter, Clue, Reply, Accept, Elicitation, Evaluate, Informative, Directive, React, Check, Conclusion, Comment, Cue, Bid, and Nomination. Meanwhile Prompt, Acknowledge, Metastatement, Loop, Silent stress, and Aside were not found during the teaching and learning process. (b) The realization of types of act Marker of act was realized by a closed class of item "Ok". Starter of act was realized by a command. Clue of act was realized by a statement. Reply act was realized by question. Accept of act was realized by a close of item "good'. Elicitation of act was realized by question. Evaluate of act was realized by statement and question tag. Informative of act was realized by a statement. Directive of act was realized by a command. React of act was realized by a non linguistic. Check of act was realized by statement. Conclusion of act was realized by a statement "so". Comment of act was realized by a statement. Nomination of act was realized by a closed class consisting of the names of the pupil "please you". Cue of act was realized by a close class of which "raise your hand". Bid of act was realized by a close class of verbal items "Miss".
\end{abstract}

Keywords: Teacher Act, Classroom interaction, Act Sinclair and Coulthard.

\footnotetext{
*Graduate Status

**Lecturer Status
} 


\section{INTRODUCTION}

\section{Background of the Study}

Classroom interaction is the action performed by the teacher and students in the teaching and learning process in the class. The purpose of teaching and learning process could be achieved through the interaction. Interaction is the collaborative exchange of thoughts, feelings or ideas between two or more people (Brown, 2000). Classroom interaction is the most important part in teaching and learning process since the purpose of the teaching and learning can only be achieved by through it. For foreign language learning, classroom is the main place where they are frequently exposed to the target language. The kind of language used by the teacher for instruction in the classroom is known as teacher's talk (Xiao Yan, 2006).

Teacher act is the teacher's utterance which contains action in communication which considering the aspect of speech situation in teaching and learning process. (Sinclair and Coulthard, 1975). It is one of the efforts of the teacher in pushing the students to do interaction in the class. The teacher initiates an interaction by greeting the students, and then explaining the materials that is related to the lesson, giving information, checking whether the students following her within the lesson, and asking a question, so the interaction can run effectively.

Based on the explanation above, in the act exchanges during the interaction in the classroom, teacher act are not appropriately done. When the teacher opened the interaction conducted, the teacher often does not pay attention to the acts. Inappropriate act by the teacher may be presented in the following example:

$\mathrm{T}$ : what is past tense? Who knows?

\section{S : (Silent)}

$\mathrm{T}$ : nobody knows. What is past tense? Who can answer it? 
$\mathrm{S}$ : past tense is action in the past mam

$\mathrm{T}$ : Good, you try to answer correctly

Based on the conversation above up, the teacher opened the interaction by directly asking the question without any introduction. Then the students were silent or they were lazy to respond, it was not because the students did not know the answer, but the teacher did not pay attention to the appropriate act. Furthermore, when teacher asked the question for the second time, the student responded the question. In real situation, teacher could give more feedback by adding information about the lesson, so there will be interaction among teacher and students in the classroom during the teaching learning process. On the other hand, students are few to respond the teacher's question. It was because the teacher did not apply the appropriate act to stimulate the students' participant in the classroom. And that is the problem of our reality during the teaching and learning process. To conduct the interaction in the classroom, among the teacher and students have to do communication. In this study, the researcher uses Sinclair and Coulthard model at the level of act to analyze the act by using the teacher talk during the interaction in the classroom interaction.

\section{REVIEW OF LITERATURE}

\section{The Role of Teacher}

Harmer (2003) stated that teacher roles have eight roles in managing a class; they are controller, organizer, assessor, prompter, participant, resource, tutor, and observer.

\section{Classroom Interaction}

Interaction is the collaborative exchange of thoughts, feelings, or ides between two or more people resulting in a reciprocal effect on each other. Theories of communicative competence emphasize the importance of interaction as human beings use in various contexts to 'negotiate' meaning, or 
simply stated to get an idea out of one person's head and into the head of another person and vice versa (Brown, $2000: 165$ ).

Classroom interaction is one of primary means by which learner accomplished in classrooms. Some decades of research showed that the learners can learn best way through interaction. Students can use all they have already learn from classroom or from the real life situations through the interaction (Rahman, 2014 : 204). They also create mutual understanding of their involvement as members in the classroom. They also create mutual understandings of their involvement as members in the classroom. In other words, through the interaction, students are socialized into particular understanding of what counts as the official curriculum and of themselves as the learners of subject matter (Walsh, 2011:187).

\section{Sinclair and Coulhard Model}

Sinclair and Coulthard (1975) developed a model for the description of teacher - pupil talk based on hierarchy of discourse units. The Sinclair and Coulthar model was devised in 1975 and slightly revised in 1992. It consist of five ranks namely lesson, transaction, exchange, move and act (Jiang, 2012 : 2147). (Nicholson, 2014 : 200) state that the Sinclair and Coulthard model propose to show how the interaction in the classroom takes place by taking a linguistic and functional look at discourse. Sinclair and Coulthard's model take a structural look at classroom conversation by breaking the discourse down into five ranks, namely: lesson, transaction, exchange, move and act,

\section{RESEARCH METHODOLOGY}

A descriptive qualitative design was used in this research. Descriptive qualitative design was chosen in order to explore and understand the social phenomenon (Creswell, 2009).Qualitative research has natural setting as the direct source of data and the key instrument of this research is the researcher itself. 
This study deals with teaching and learning process in the classroom focus on the types of acts that teacher used in classroom interaction and how the types are realized by the teacher in classroom interaction.

The data of this study were the utterances produced by the English teacher during teaching learning process in the classroom. The source of the data was an English teacher of SMAN 1 Kutacane. The chosen class was in grade ten. The utterances of the English teacher were recorded in order to gain the data. Then, it was transcript.

The techniques of collecting data were Observation, and Recording. In observation, the researcher needed notebook during observation in the classroom. The classroom interaction observed through field notes based on what the writer see: setting, manner and whatever in accordance with real situation. In recording, the writer collected more information about type of acts and how the types are realized that was used by English teacher. The recording had been recorded the whole interaction between teacher and students, especially for the teacher utterances.

In conducting this research, the data had been analyzed by using the data analysis based on Sinclair and Coulthard Model. There were transcript the teacher's utterances in teaching-learning process in order to get the result, segmenting the transcript that had several sentences into clauses,analyzing the type of acts andhow the types are realized that teacher used in classroom interaction.

\section{RESEARCH FINDINGS AND DISCUSSIONS}

\section{Research findings}

1. The researcher found that there were 16 types of acts found in the English classroom interaction, namely: starter, reply, accept, elicitation, evaluate, informative, marker, directive, react, check, bid, cue, nomination, conclusion, clue, and comment. Meanwhile Prompt, Acknowledge, Metastatement, Loop, silent stress, and Aside were not found during the teaching and learning process. 
2. The realization of types of acts in English classroom interaction that teacher used based on Sinclair and Couthard model that the researcher found there were: Markerwas realized by a closed class of item 'Ok'. Starter wasrealized by a command. Cluewas realized by a statement. The Replywas realized by statement "Kosakata in English apa" that teacher question. The student answer is the reply. Accept was realized by a close of item 'Bagus' in English classroom interaction that the teacher used. Elicitationwas realized by question in English classroom interaction that teacher asked to the student. Evaluate was realized by statement and question that teacher asked to the students for evaluation. Informativewas realized by a statement. Directivewas realized by a command. Reactwas realized by a non-linguistic. Checkwas realized by a closed class of polar question concerned with being "understand". Conclusionwas realized by a statement "so". Commentwas realized by a statement. Nomination was realized by a closed class consisting of the names of the pupil "cobakkamu. Cue was realized by a close class "raise your hand". Bidwas realized by a close class of verbal items "Miss" and raised hand.

\section{Discussion}

1. Firstly, there were 16 types of acts found in English classroom interaction that teacher used based on Sinclair and Coulthard Model. The overall produced by the teacher were 282 of utterances. Marker act was found 15 times used by teacher, Starter act was found 4 times used by teacher, Clue act was found 15 times used by teacher, Reply act was found 89 times used by students, Accept acts was found 28 times, Elicitation act was found 30 times, Evaluation act was found used by teacher in 14 time, Informative act was found in 6 times, Directive act was found used in 15 times, React act was found in 1 time, Check act was found 19 times, Conclusion act was found in 3 times, Comment act was found 14 times, Nomination act was found 7 times, Cue act was found in 1 time, Bid act was found 6 times. Prompt, Acknowledge, Metastatement, Loop, Silent stress, and Aside were not found during the teaching and learning process. 
Elicitation was mostly related to obtain verbal responses from the students. The teacher used elicitation particularly when the teacher was trying to gain students' participation in the class, which was realized by questioning. By initiation act questions to the students as a request for the information, the interaction will be motivated quickly because questions were the commonest and the most important the way to make students to talk in the classroom interaction (Liu Yanfen\&Yiqin, 2010). Moreover, Weihua $\mathrm{Yu}$ (2009:152) stated that questioning is reported as one of commonly used strategies as the success of a class largely depends on questioning and feedback.

2. The realization of types of acts found in the English classroom interaction that teacher used was takes an important role to stimulate the students' participation. The Marker was realized by a closed class of item "Ok'. The teacher used closed class of item "Ok" in classroom interaction to catch the attention of the students in the opening part of lesson. Starter was realized by a command. The teacher gives command to direct attention of students. Clue was realized by a statement. The Replywas realized by answer that teachers' question. Its function is to provide a linguistic response which is appropriate to the elicitation. Acceptwas realized by a close of item 'Bagus' in English classroom interaction that the teacher used. Its function is to see the reaction of the students answer was appropriate. The Elicitationwas realized by question in English classroom interaction that teacher asked to the student. Its function is to request a linguistic response. Evaluate realized by statement and question tag that teacher asked to the students for evaluation. Informativewas realized by a statement. It differs from other used of statement. Its function is to prove the information to students. Directivewas realized by a command. Its function is to request a non linguistic response. Reactwas realized by a non linguistic. Its function is to provide the appropriate non linguistic response defined by the preceding directive. Checkwas realized by a closed class of polar question concerned with being "understand". 
The function of check is to an able the teacher to ascertain whether there are any problems or understand the successful progress of the lesson. Conclusionwas realized by a statement "so". The function is again to help the pupils understand the structure of the lesson. Commentwas realized by a statement. Its function is to exemplify additional information. Nomination was realized by a closed class consisting of the names of the pupil "cobakkamu". The function of nomination is to call on or give permission to contribute to the discourse. Cue was realized by a close class "raise your hand". Its function is to evoke an appropriate bid. Bidwas realized by a close class of verbal items "Miss" and raised hand. Its function is to signal to contribute to the discourse.

\section{CONCLUSIONS AND SUGGESTIONS}

\section{Conclusions}

1. The types of acts was found in the teacher used in English classroom interaction that teacher used in SMAN 1 Kutacanewas dominated by the Elicitation. It was found that 16 types of acts namely starter, reply, accept, elicitation, evaluate, informative, marker, directive, react, check, bid, cue, nomination, conclusion, clue, and comment. Meanwhile Prompt, Acknowledge, Metastatement, Loop, Silent stress, and Aside were not found during the teaching and learning process.

2. The realization of types of act Marker of act was realized by a closed class of item "Ok'. Starter of act was realized by a command. Clue of actwas realized by a statement. Reply actwas realized by question. Accept of act was realized by a close of item “Bagus'. Elicitation of act was realized by question. Evaluate of act was realized by statement and question tag. Informative of act was realized by a statement. Directive of act was realized by a command. React of act was realized by a non 
linguistic. Check of act was realized by statement. Conclusion of actwas realized by a statement "so". Comment of act was realized by a statement. Nomination of act was realized by a closed class consisting of the names of the pupil "cobakkamu". Cue of act was realized by a close class of which "raise your hand". Bid of act was realized by a close class of verbal items "Miss".

\section{Suggestions}

1. Teacher

By applying the appropriate acts, the teacher can stimulate the students' participations. It is necessary for the teachers to recognize the acts they use to interact with the students in the classroom to get the students' participations. Then, the class will run successfully.

2. Students

The students should dare to speak up, because in the classroom they are allowed to makes mistakes, and give more responses to the tacher's question.

3. The next researcher

This research is about teacher and students interaction done in the classroom based on Sinclair and Coulthard model. It is finally suggested that the other researcher should conduct further studies about it which will be a very useful reference to the teachers' and students' needs in teaching learning process.

\section{REFERENCES}

Brown, H.D (2007). Principles of Language Learning and Teaching USA: Pearson Education. 
Coulthard, M. and D. Brazil.(1992). 'Exchange structure'.In Coulthard. M. (Ed) 1992. Advances in Spoken Discourse analysis. 50 - 78. London: Routledge.

Derakhsan, A. (2015). Features of Classroom Discourse.International Journal of Basic Sciences \& Applied Research. Vol., 4(4), 240 - 244.

Harmer, J. (2003).The Practice of English Language Teaching.Third Edition. New York : Longman Inc.

Jiang, X. (2012).A Study of College English Classroom Discourse. International Journal Theory and Practice in Language Stidues, 2 (10), 2146 - 2152. Findland: Academy.

Larsari, V.N (2011). Learners'communicative competence in English as a foreign language (EFL). Iran: Islamic Azab University.

Markee, N. (2015).The Handbook of Classroom Discourseand Interaction. United Kingdom: John Wiley \& Sons.

Nicholson, S.J. (2014). An Imptepus for Change: Classroom Analysis Using Sinclair and Coulthard's Model of Spoken Discourse. South Korea: International Journal of Linguistics. Vol. 6, Vol. 6, No. 2, 2014, pp. 200 $-202$.

Rahman, M.M. (2014). Learning English Through Interaction in an EFL Classroom .International Journal of Languages and Literatures, 2(2), 203 - 217. America: America Research Institute for Policy Development

Sinclair., and Coulthard. 1975. Towards Analysis of Discourse: The English Used by Teacher and Pupils. London: Oxford University Press.

Tsui, A.B.M. (1995). Introducing Classroom Interaction. London: Penguin

Walsh, S.(2011). Exploring classroom discourse.London:Routledge

Xiaohui, S. (2011).A disertation of Teacher Talk and EFL in University Classroom. China: Chongqing Normal University \& Yangtze Normal University

Yanfen, L. \&Yuqin.Z. (2010).A Study of Teacher Talk in Interactions in English Classes. Harbin Institute of Techonogy: Chinese Journal of Applied Linguistics (Bimonthly) Vol. 33 No.22 